\title{
EIN NEUES
}

\section{EVANGELIENFRAGMENT}

VON

\section{ADOLF JACOBY}

MIT VIER TAFELN IN LICHTDRUCK.

STRASSBURG

VERLAG VON KARL J. TRÜBNER

1900. 



\section{MEINEN ELTERN}

IN LIEBE GEWIDMET. 
